\title{
A VEZETÉSI TANÁCSADÁSI SZOLGÁLTATÁS IGÉNYBEVÉTELE SPECIÁLIS OKAINAK VÁLTOZÁSA 2001 ÉS 2016 KÖZÖTT
}

\section{CHANGES IN SPECIFIC REASONS FOR USING MANAGEMENT CONSULTING SERVICES BETWEEN 2001 AND 2016}

\author{
Tokár-Szadai Ágnes PhD* \\ Gazdálkodástani Intézet, Gazdaságtudományi Kar, Miskolci Egyetem, Magyarország \\ https://doi.org/10.47833/2020.2.ECO.002
}

\section{Kulcsszavak: \\ vezetési tanácsadás \\ tanácsadási területek vállalkozások életciklusa \\ kérdőíves felmérés \\ Északkelet-Magyarország}

\section{Keywords:}

management consulting

consulting areas

business life cycle

survey

Northeast Hungary

\section{Cikktörténet:}

Beérkezett 2019. szept. 19.

Átdolgozva 2019. okt. 24.

Elfogadva 2019. nov. 10.

\begin{abstract}
Összefoglalás
A Miskolci Egyetem Gazdálkodástani Intézete 2001-ben, 200506-ban, 2011-12-ben, majd 2015-16-ban kérdőíves felmérést végzett tanácsadó cégek valamint ügyfeleik körében. A felmérések célja a vezetési tanácsadási piac feltérképezése, valamint a tanácsadók és ügyfeleik tanácsadási értékrendjének összehasonlítása volt. Jelen tanulmányban a vezetési tanácsadási szolgáltatás igénybevétele speciális okainak változását vizsgálom 2001 és 2016 között a vállalkozások életciklusának függvényében Északkelet-Magyarországon a tanácsadók ügyfeleinek értékitélete alapján, valamint, hogy a gazdaság általános állapota milyen hatást gyakorol a tanácsadási szolgáltatás igénybevételére.

\section{Abstract}

The Institute of Business Sciences of the University of Miskolc conducted a questionnaire survey in 2001, 2005-06, 2011-12 and then in 2015-16 among consulting firms and their clients. The purpose of the surveys was to map the management consulting market in Northeast Hungary and to compare the advisory value system of consultants and their clients. In this study I present the changes in the specific reasons for the use of management consulting services based on the judgment of the consultants' clients between 2001 and 2016, depending on the lifecycle of business, and the impact of the overall state of economy on consulting services.
\end{abstract}

\section{Bevezetés}

A Miskolci Egyetem Gazdálkodástani Intézete 2001-ben, 2005-06-ban, 2011-12-ben, majd 2015-16-ban kérdőíves felmérést végzett tanácsadó cégek valamint ügyfeleik körében. A felmérésben 2001-ben 362, 2005-06-ban 294, 2011-12-ben 77, 2015-16-ban 48 vállalkozás, és 2001-ben 83, 2005-06-ban 88, 2011-12-ben 58, 2015-16-ban 34 tanácsadó vett részt. A felmérések célja a vezetési tanácsadási piac feltérképezése, valamint a tanácsadók és ügyfeleik

\footnotetext{
* Tel.: +36 46565 111/1004;

E-mail cím: vgtsza@uni-miskolc.hu
} 
tanácsadási értékrendjének összehasonlítása volt. Jelen tanulmányban a vezetési tanácsadási szolgáltatás igénybevétele speciális okainak változását vizsgálom 2001 és 2016 között a vállalkozások életciklusának függvényében Északkelet-Magyarországon a tanácsadók ügyfeleinek értékítélete alapján, valamint, hogy a gazdaság általános állapota milyen hatást gyakorol a tanácsadási szolgáltatás igénybevételére.

\subsection{A vezetés tanácsadás meghatározása, területei}

A vezetési tanácsadás a szervezetek számára értékteremtés, tudást, technikákat, eszközöket használ fel ennek érdekében. A tanácsadási szakma elnevezése a hazai és nemzetközi szakirodalomban nem egységes, számos megközelítési mód, és meghatározás létezik [1]. Jelen tanulmányban, és az alapjául szolgáló felmérésekben [2] Kubr megközelítését alkalmazom, aki a következő fogalmat használja a tanácsadással kapcsolatban: „A vezetési tanácsadás egy olyan független, szakértői szolgáltatás, melyet szervezetek és azok vezetői számára nyújtanak abból a célból, hogy segítsék a szervezeteket céljaik elérésében, a problémák feltárásában, megoldásában, új lehetőségek felkutatásában és azok megoldásában, a szükséges tudás elsajátításában és a változások megvalósításában." [3] Kiemeli a tanácsadók szerepét az információ és szaktudás nyújtásában, a döntéshozatalban és megvalósításban jelentkező bizonytalanság csökkentésében. A korábbi kutatások [4]; [5] alapján a bizonytalanságoknak három típusa merül fel a tanácsadók kiválasztásánál és igénybevételekor [6]:

- A teljesítménnyel kapcsolatos bizonytalanság: Az ügyfél számára problémás, hogy mit is várhat a tanácsadótól, hogyan tudja megkülönböztetni a képzett tanácsadót a képzetlentöl, hogyan tudja megjósolni a tanácsadó cég szakmai hátterét és a fenntarthatóságot [4].

- A kapcsolati bizonytalanság: több tudós [7] [8] is rámutatott, hogy az ügyfelek hajlamosak elbizonytalanodni, hogy megbízhatnak-e abban, hogy a tanácsadók az ő érdeküket tartják szem előtt, vagy elsősorban a saját érdekeik határozzák meg cselekedeteiket.

- Pszichoszociális bizonytalanság: A menedzserek egy ismeretlen kívülállóval kötnek szerződést annak érdekében, hogy szervezetük eredményeket érjen el, és ez a szerződés aggodalmat és szkepticizmust eredményezhet a szervezeten belül [9]. A munkavállalók visszautasíthatják az együttmüködést, információkat rejthetnek el, és cinikusak lehetnek, ami veszélyeztetheti a projektet [10].

Ezen bizonytalanságok kezelésében a menedzsereknek el kell fogadniuk és fogadtatniuk a tanácsadók igénybevételét saját magukkal és munkatársaikkal [11].

A FEACO (European Federation of Management Consultancies Associations) [21] 2000 és 2004 között a következőképpen határozza meg a tanácsadási szolgáltatás területeit (1. táblázat):

1. Táblázat. Tanácsadási szolgáltatások

\begin{tabular}{|c|c|}
\hline $\begin{array}{l}\text { Stratégiai tanácsadás } \\
\text { Stratégiai tervezés } \\
\text { Szervezetfejlesztés } \\
\text { Fúziók, felvásárlások } \\
\text { Piackutatás } \\
\text { Marketing és cégkommunikáció } \\
\text { Pénzügyi tanácsadás }\end{array}$ & $\begin{array}{l}\text { Humán eröforrás tanácsadás } \\
\text { Fejvadászat } \\
\text { Oktatás } \\
\text { Jövedelem, jutalmazás, juttatások } \\
\text { Outplacement }\end{array}$ \\
\hline $\begin{array}{l}\quad \text { Müködési (operatív) tanácsadás } \\
\text { Üzleti folyamatok átszervezése } \\
\text { Változáskezelés } \\
\text { Projektvezetés } \\
\text { Ellátási lánc irányítása }\end{array}$ & $\begin{array}{l}\text { Informatikai tanácsadás } \\
\text { Általános informatikai tanácsadás } \\
\text { Rendszerfejlesztés, rendszerintegráció }\end{array}$ \\
\hline $\begin{array}{c}\text { Outsourcing } \\
\text { (tevékenység kihelyezése, tevékenység }\end{array}$ & \\
\hline
\end{tabular}


kiszervezése)

Forrás: FEACO 2000-2004

A klasszikus értelemben vett, szigorúan értelmezett vezetési tanácsadás (management consulting) jelentése az elmúlt évtizedekben jelentősen kibővült, és a kereslet az újabb területek irányába tolódott el. Habár a majdnem fél évszázada kialakult vezetési tanácsadási szövetségek elnevezésüket nem változtatták meg, de hangsúlyozzák, hogy tevékenységük komplexebbé vált, és folyamatosan fejlődik. Így a "management consulting” kifejezés jelentése is változik. A tanácsadási piacon jelenlévő tendenciákat figyelembe véve változtatta meg a FEACO [21] kategóriáit 2005-ben, ezt foglalja össze a 2. táblázat:

2. Táblázat. A tanácsadás területei FEACO 2005-2013

\begin{tabular}{|c|c|}
\hline Üzleti tanácsadás & Üzleti tanácsadás \\
\cline { 1 - 1 } Informatikai tanácsadás & Stratégiai tanácsadás \\
Rendszerfejlesztés-integráció & Működési (operatív tanácsadás) \\
Outsourcing & Projekt menedzsment \\
Egyéb szolgáltatások & Változás menedzsment \\
& HRM tanácsadás \\
\hline
\end{tabular}

Forrás: FEACO 2005

A FEACO [21] 2014-ben a változásokat és tendenciákat figyelembe véve ismét megváltoztatta a kategóriáit, 2014-től felméréseiben a következő tanácsadási szolgáltatási területeket szerepelteti:

- Stratégiai tanácsadás (PI. szervezeti és üzleti tervezés, optimalizálás, üzleti modellezés, piacelemzés és stratégiai fejlesztés);

- Müködési tanácsadás (PI. BPR, CRM, költségcsökkentés, gyártás, $K+F$, termékfejlesztés);

- Marketing, eladás (PI. eladásmenedzsment, termék portfólió menedzsment, digitális marketing);

- Pénzügy, kockázatmenedzsment (PI. tervezéselemzés és újradefiniálás, költségvetési és teljesítmény menedzsment modellek, vállalati kockázatok optimalizálása);

- Emberek és változás (PI. változásmenedzsment, HR tanácsadás, HR stratégia, teljesítménymérés, kompenzációs és nyugdíjrendszerek, kompetenciafejlesztő programok, coaching);

- Technológiai tanácsadás (IT stratégiák értékelése, üzleti folyamatokhoz igazítása, új technológiák tervezésével és bevezetésével kapcsolatos döntések stratégiai támogatása, hálózat és biztonsági adatközpont építés);

- Egyéb szolgáltatások (képzés, piaci tanulmányok, kihelyezés, vezető kiválasztás, toborzás).

Meg kell jegyezni, hogy a kategóriák megváltozásával a 2005 elötti és utáni adatok közvetlenül nem összehasonlíthatóak. Egyes kategóriák összevonásával az összehasonlíthatóság elvileg biztosítható, de a gyakorlatban nem teljes körüen [12]. Jelen tanulmányban, és az alapjául szolgáló felmérésekben a FEACO 2005 előtti kategória rendszerét alkalmaztam.

\section{Az empirikus felmérések módszertani háttere}

Az empirikus vizsgálat alapját jelentő kérdőív a korábbi, külföldi kutatások során alkalmazott kérdőívek figyelembevételével állt össze. A kérdőív szerkesztésénél lényeges szempont volt, hogy egy-egy témát több oldalról is megvilágítsanak a kérdések, növelve ezzel a válaszokból levonható következtetések megbízhatóságát. Az empirikus vizsgálat két részből tevődött össze (1. ábra) [2]: 


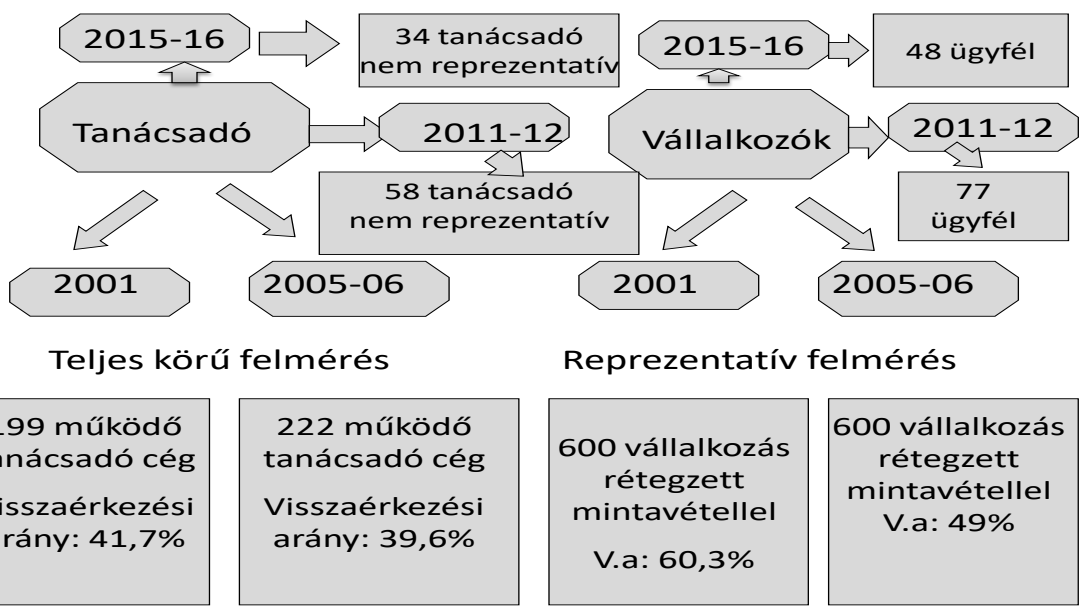

1. ábra. Az empirikus vizsgálatok felépitése

Az empirikus felmérés alapjául szolgáló tanulmányok föként angol és német nyelvü [3] [13] [14] és magyar szerzők munkái [15] [16] melyekben kiemelésre kerülnek azok a tényezők, melyek a tanácsadók igénybevételét motiválják.

A kutatás kiterjedt egyrészt a Borsod-Abaúj-Zemplén megyei, müködő vállalkozások megkérdezésére a tanácsadási szolgáltatás igénybevételére vonatkozóan. A cégek kiválasztása a tevékenységi kör alapján részletezett vállalkozások közül történt, a területi elhelyezkedés arányait figyelembe véve, egyszerü véletlen mintavétellel. 2001-ben 362 db, 2005-06-ban 294 db értékelhető kérdőívet sikerült kitöltetni. (A visszaérkezési arány 2001-ben 60,3\%, 2005-06-ban $49 \%$ volt.) A vissza nem érkezett kérdőívek miatt- a szolgáltatás egy kicsit alul, az ipar és kereskedelem egy kicsit felülreprezentált volt 2005-ben, az eltérés nem volt számottevő, jól követte a megyei arányokat. A kiválasztott tanácsadók ügyfelei 2011-12-ben és 2015-16-ban is valamennyi iparágat képviseltek (2.ábra).

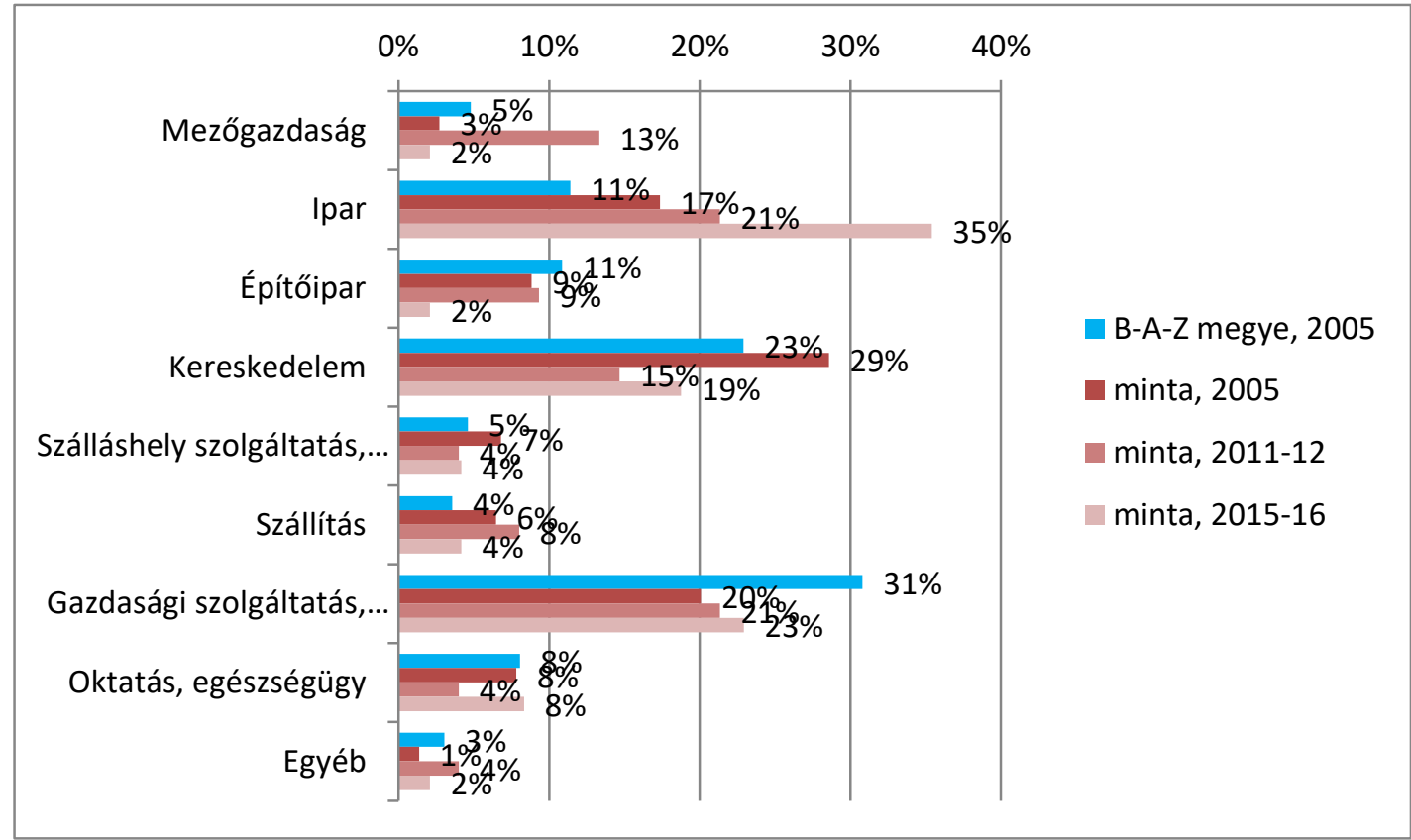

2. ábra. A B-A-Z megyei vállalkozások (2005) és a minta (2005, 2011-12, 2015-16) tevékenységi kör szerinti összetétele

A kutatás másik része a tanácsadó vállalatok megkérdezésére épült. 2001-ben és 2005-ben teljes körü felmérést végeztünk a 7414 „üzletviteli tanácsadás” TEÁOR számú, Borsod-Abaúj- 
Zemplén megyei székhelyű tanácsadó cégek körében. 2000 decemberében 199 tanácsadó cég müködött megyénkben, 2005-ben 222, valamennyit felkerestük. A kérdőív kitöltését 2001-ben 83, 2005-06-ban 88 tanácsadó vállalta. A visszaérkezési arány kisebb volt, mint a vállalkozások körében, 40\% körüli (2001-ben 41,7\%, 2005-06-ban 39,6).

2011-12-ben és 2015-16-ban a tanácsadók és ügyfeleik kiválasztása nem reprezentatív mintavétellel, hanem úgynevezett hólabda módszerrel történt: a kiválasztott tanácsadók ügyfeleiket, az ügyfelek más vállalkozásokat és tanácsadóikat vonták be a felmérésbe. Területi vonatkozást illetően egyetlen kritériumot állítottunk: vagy a tanácsadónak vagy ügyfelének északkelet-magyarországi (Borsod-Abaúj-Zemplén, Heves, Nógrád, Szabolcs-Szatmár-Bereg, Hajdú-Bihar megyei) székhellyel kellett rendelkeznie. A kérdőívet kitöltő vállalkozók főként BorsodAbaúj-Zemplén, tanácsadóik pedig föként Pest és Borsod-Abaúj-Zemplén megyéből kerültek ki (3. ábra).

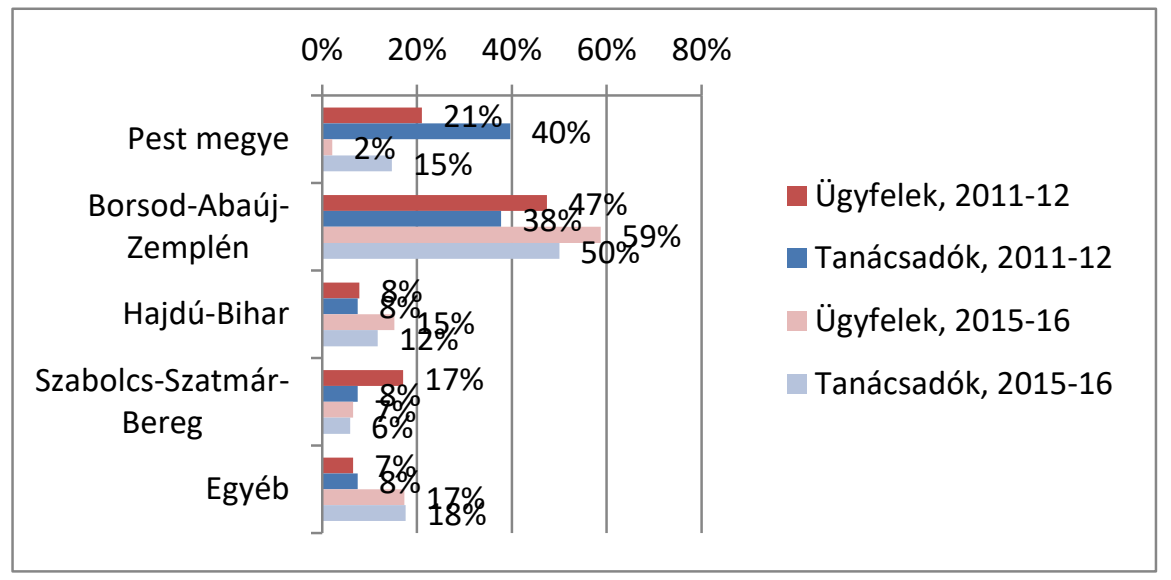

3. ábra. A vizsgált tanácsadók és ügyfeleik székhely szerinti megoszlása, 2011-2012, 201516

A tanácsadói kérdőívet 58 vállalkozás töltötte ki 2011-12-ben, és 34 2015-16-ban. (Tanácsadónak tekintettem azon vállalkozókat, akik tevékenységeik között megjelölték az „üzletviteli tanácsadást”. A tanácsadói kérdőívet a tanácsadási tevékenységre vonatkozóan töltötte ki egy tanácsadást folytató kolléga.) A megvizsgált tanácsadók 1-2 ügyfele pedig kitöltötte a „tanácsot igénybevevő vállalatok tanácsadási tapasztalatára” vonatkozó kérdőívet (77 kitöltött kérdőív érkezett vissza 2011-12-ben és 48 2015-16-ban): így összehasonlíthatóvá vált, hogy a tanácsadók hogyan látják saját magukat, kompetenciáikat, tevékenységük eredményét, hogyan látják őket ügyfeleik, vannak-e eltérések, miből adódnak ezek. A szolgáltatást igénybevett vállalkozók valamennyi iparágat képviseltek. A korábbi felmérésekkel történő összehasonlíthatóság nem biztosítható teljes mértékben, de a tendenciákra következtetni lehet.

A megvizsgált tanácsadók ügyfeleinek (a szolgáltatást igénybevett vállalkozások) foglalkoztatottak száma szerinti megoszlását szemlélteti a 4. ábra. 


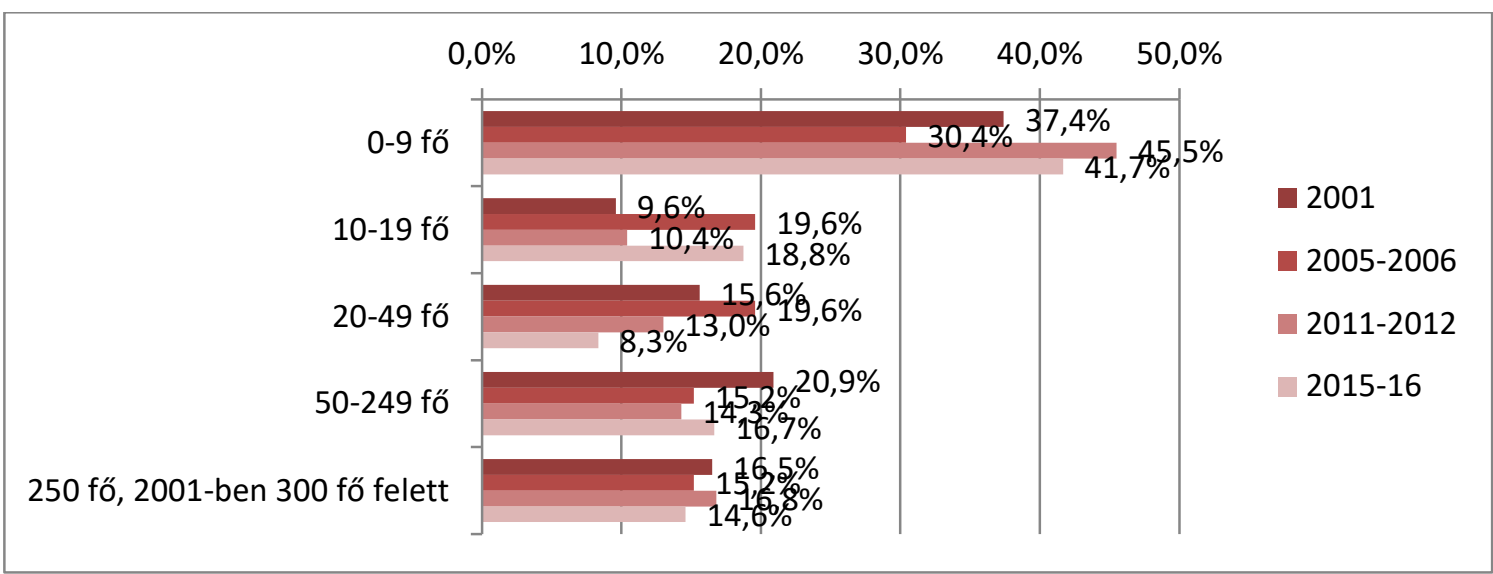

4. ábra: A felmérésben részt vett tanácsadók ügyfeleinek foglalkoztatottak száma szerinti megoszlása 2001, 2005-06, 2011-12, 2015-16

A kérdőív kitöltési hajlandóság a nagyobbak esetében lényegesen magasabb volt, így valamennyi mintában felülreprezentáltak (a megyei arányukhoz képest nagyobb számban vettek részt a felmérésekben). Létszám kategória szerinti reprezentativitásra az értékelhetőség növelése érdekében 2001-ben és 2005-06-ban sem törekedtünk, mivel a nagyobb vállalkozások jobban megengedhették maguknak, és szívesebben vették igénybe a szolgáltatást, így indokolt volt a felülreprezentálásuk, mivel többen rendelkeznek tapasztalattal a területen. 2011-12-ben és 201516-ban csak a kiválasztott tanácsadók ügyfeleit vizsgáltuk, így, mint ahogy várható volt, a nagyobb létszámú vállalkozások jelentősen felülreprezentáltak. A vizsgált vállalkozások valamennyi létszám kategóriát képviselnek, de mint ahogy a 4. ábra mutatja, főként mikrovállalkozások vettek részt mind a négy felmérésben.

A kérdőívekkel nyert adatok feldolgozásához az SPSS 14.0 programcsomagot alkalmaztam. Az elemzés kereszttábla elemzéssel (függetlenségvizsgálattal), varianciaanalízissel, valamint korrelációelemzéssel történt, a társadalomtudományi kutatásokban szokásos $5 \%$-os szignifikancia szinten.

\section{Eredmények, tárgyalás}

\subsection{A vezetési tanácsadási szolgáltatás igénybevétele speciális okainak változása 2001 és 2016 között a vállalkozások életciklusának függvényében}

A vállalkozás indítása gazdasági és adminisztratív feladatokkal jár. Az indulást mindig piackutatásnak kellene megelőznie. Indokolt felmérni, hogy mi az a piacon még ki nem elégített termék vagy szolgáltatás iránti igény, melyet a potenciális vásárlói meg is tudnak fizetni. $A$ piackutató társaságok nagy tapasztalattal rendelkeznek ezen a téren. Az üzleti terv elkészítése nem egyszerü technikai, formai kérdés, hanem tervezés. Végig kell gondolni az eszközöket és forrásokat, a várható bevételeket és költségeket. A tervezés része a leendő partnerek: a szállítók és vevők felkutatása is. Az üzleti terv a vállalkozás stratégiája, a tevékenységének iránymutatója, a partnerekkel és bankkal való tárgyalás vezérfonala [22]. Elkészítése mindig a vállalkozás feladata, de az elökészítésbe bevonhat külső szakembereket. Ugyanakkor a társasági szerződés elkészítését, a cégbírósági, banki és egyéb eljárásokat a rutinnal és kialakult kapcsolat rendszerrel rendelkező tanácsadók egyszerübben végig tudják vinni, mint a kezdő vállalkozó. Az indulás szakaszában az önfinanszírozás nehézségekbe ütközhet, a hitel szinte lehetetlen, a kockázati tőkének van kizárólagos szerepe. Az adósság (hitel) felvételének nincs bizonyító erejü alapja, sem tárgyi fedezete. A vállalkozás indítása céljából igénybevett tanácsadási szolgáltatás változását szemlélteti az 5. ábra a megvizsgált ügyfelek százalékában 2001 és 2016 között. 


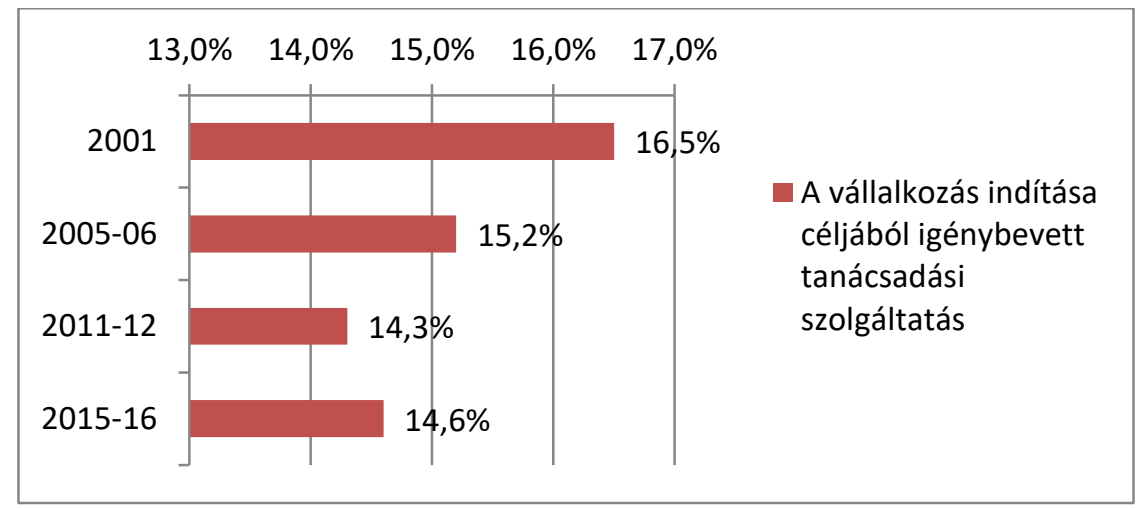

5. ábra: A vállalkozás indítása céljából igénybevett tanácsadási szolgáltatás alakulása a megvizsgált ügyfelek \%-ában 2001 és 2016 között

A vizsgált évtizedben kis mértékben csökkent a vállalkozás indítása céljából igénybevett tanácsadási szolgáltatás: ez a vállalkozás indításával kapcsolatos adminisztrációs terhek csökkenésével magyarázható. A tanácsadók ügyfeleinek 14-16\%-ka vette igénybe a szolgáltatást a vállalkozásuk indításának elősegítése céljából.

A növekedés szakaszában a készletszint felduzzad, a vevő állomány ugrásszerűen megnő. A szállító jelentős összegű hitelt nyújt, a jövedelmezőség javul. A szervezet egyre nagyobb létszámú, a munkamegosztás egyre bonyolultabb. Ki kell alakítani a Szervezeti és Müködési Szabályzatot, a munkaköri, hatásköri és felelösségi leírásokat, a bérezési és ösztönzési szabályzatokat, valamint a munkavállalók jogait tartalmazó Kollektív Szerződéseket és egyéb a működéshez és irányításhoz szükséges belső szabályzatokat. A vállalkozó gyakran nem ismeri fel azt a pontot, amikor ezeket el kell készíteni. A külső objektív tanácsadó éppen ezekre vezeti rá a vállalkozót. A probléma megoldatlansága esetén a probléma felmerülésekor kibontakozó érdekellentétek a vállalkozás müködőképességét veszélyeztetik. A vállalkozás piaci jelenlétének erősítéséhez egyaránt szükség van a tanácsadó által képviselt magas színvonalú szakmai és módszertani ismeretekre. (PI. reklámügynökségek, PR szakemberek igénybevétele.) Ebben a szakaszban az önfinanszírozás még elégtelen, a hitel felvétele nehézkes, ugyanis a piacon jelenlévő, ismert és megbízható adósokkal kell versenyeznie. Ez a finanszírozási paradoxon, ugyanis ekkor volna a társaságnak legnagyobb szüksége a hosszú lejáratú kölcsönre az értékesítés növelése érdekében. A kockázati tőketársaságok itt is lényeges szerepet játszanak a finanszírozásban [17]. A vállalkozás növelése, fejlesztése céljából igénybevett tanácsadási szolgáltatás változását szemlélteti a 6. ábra 2001 és 2016 között a megvizsgált ügyfelek százalékában.

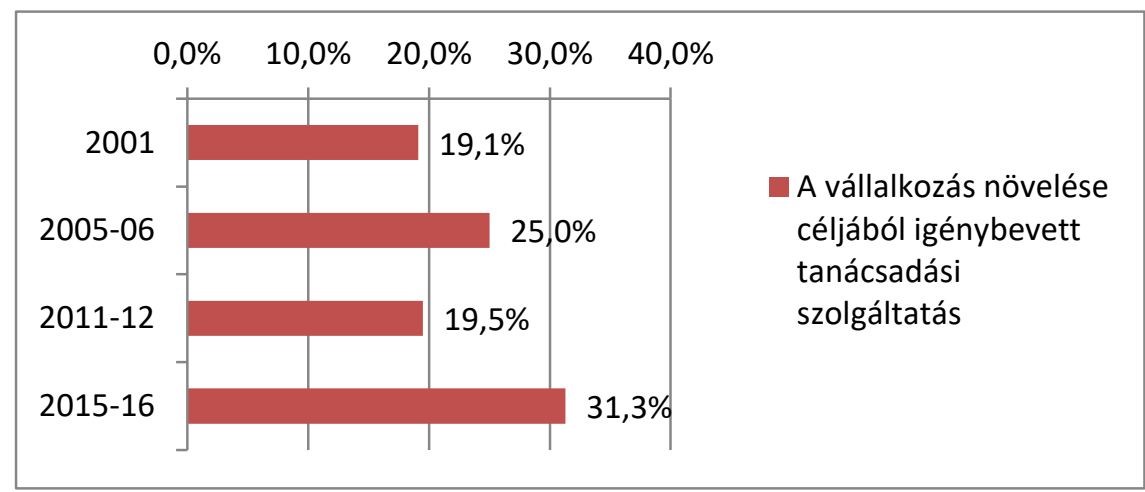

6. ábra. A vállalkozás növelése céljából igénybevett tanácsadási szolgáltatás alakulása a megvizsgált ügyfelek \%-ában 2001 és 2016 között 
2001 és 2005-06 között jelentősen növekedett a szolgáltatást a vállalkozás növelése, fejlesztése céljából igénybevett ügyfelek aránya: 2001-ben minden ötödik, 2005-06-ban minden negyedik ügyfél jelölte meg, hogy a vállalkozásuk növelés érdekében fordultak tanácsadóhoz. Ebben szerepet játszhatott Magyarország 2004-es csatlakozása az Európai Unióhoz: a csatlakozást közvetlenül megelőző és az azt követő időben a vállalkozások előtt álló együttműködési, fejlesztési és pályázati lehetőségek bővülése. 2011-12-ben csökkent a tanácsadóhoz a vállalkozás fejlesztése érdekében fordulók aránya: ez a 2008-as pénzügyi világválság elhúzódásával, és az azt követő megszorításokkal, recesszióval magyarázható. A válság lecsengését követően jelentősen növekedett a vállalkozásuk bővítése érdekében tanácsadóhoz fordulók aránya: 2015-16-ban már majdnem minden harmadik ügyfél jelölte meg ezt az okot.

Az érett, "felnőtt korban lévő" vállalatok számára a tanácsadók legkülönbözöbb területen kínálnak szolgáltatást (PI. reorganizáció, hatékonyság javítás, átvilágítás, szervezetfejlesztés, stratégiai tervezés, humánerőforrás tanácsadás, vállalat-finanszírozási tanácsadás, pénzügyi tervezés, tőzsdei bevezetés, fúziós-bekebelezési üzletág stb.). A stratégiai gondolkodás: a jövőbeni szükségletek megfogalmazása, az igények felkeltése, a vevő igényeinek maximális kielégítése fontos a versenyképesség megörzése érdekében. Nem szabad elfelejtkezni a szervezetfejlesztés fontosságáról: a szakemberek célzott képzése és továbbképzése, az együttműködés, a kommunikációs csatornák és technikáinak kialakítása, a csoportmunkában történő probléma meghatározás és megoldás igényének kiépítése, a szervezeti kultúra kialakítása és ápolása (hosszútávon befolyásolják a vállalat ütőképességét). Az igénybevett tanácsadási területek változását szemlélteti a 7. ábra 2005 és 2016 között a tanácsadási szolgáltatást igénybevett vállalkozások (ügyfelek) százalékában.

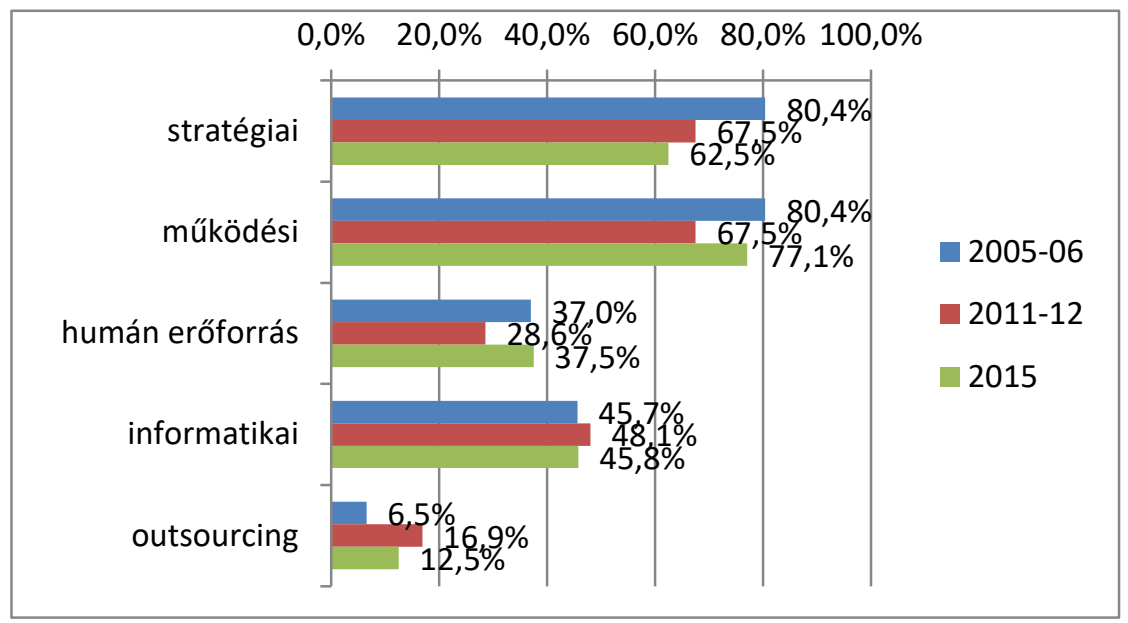

7. ábra. Az igénybevett tanácsadási területek a megvizsgált ügyfelek \%-ában 2005-06, 2011-12, 2015-16

A vizsgált régióban -a magyarországi adatokhoz hasonlóan- a két legfontosabb terület a stratégiai és a müködési tanácsadás. 2005 és 2016 között mindkét terület részaránya csökkent, de még mindig meghatározó: a vizsgált vállalkozások 80,4\%-a 2005-ben mindkét területen igénybe vette a szolgáltatást, 2015-16-ban kevesebb mint kétharmada $(62,5 \%)$ stratégiai, több mint háromnegyede $(77,1 \%)$ müködési tanácsadási szolgáltatást vett igénybe. A harmadik legfontosabb terület az informatikai tanácsadás, melynek jelentősége nem változott a vizsgált időszakban: a vizsgált vállalkozások kicsit kevesebb mint fele 46\%-48\%-a bízott meg informatikai tanácsadót. A humán erőforrás menedzsment tanácsadási szolgáltatás részaránya csökkent $37 \%$-ról $28,6 \%$-ra 2005 és 2012 között a válaszadók \%-ában, ebben valószínüleg a 2008-as válság megszorító intézkedései is közre játszottak. A válság lecsengésével visszaállt a szolgáltatás iránti igény. A legalacsonyabb az outsourcing (kiszervezési tanácsadás) iránti kereslet, de népszerüsége jelentősen növekedett: 6,5\%-ról 16,9\%-ra 2001 és 2012 között -ebben közre játszottak a válság miatt szükségessé vált racionalizálások. A válságot követően 2016-ra, kicsit csökkent a részaránya 12,5\%-ra. Meg kell jegyezni azonban, hogy a magyar köztudatban nem szerepel önálló területként, 
a kimutatások alapját képező felmérésekben inkább más tanácsadási területek (föként operatív vagy informatikai tanácsadás) részeként jelenik meg.

Az érettség szakaszában az önfinanszírozás elegendő (a tevékenység által létrehozott belső forrás már elégséges a tevékenység szinten tartásához). A vállalat stabil, jó adósnak minősül, a profitéhes bank szívesen nyújt hitelt. Igénybevétele azonban nem mindig szükséges. A vállalkozás stabilitásának megőrzése céljából igénybevett tanácsadási szolgáltatást szemlélteti a 8.ábra a megvizsgált ügyfelek százalékában:

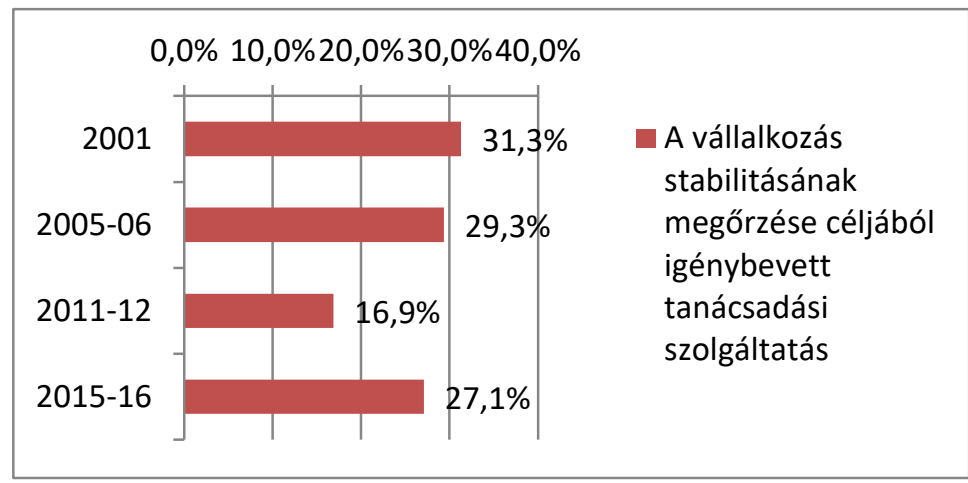

8. ábra. A vállalkozás stabilitásának megőrzése céljából igénybevett tanácsadási szolgáltatás alakulása a megvizsgált ügyfelek \%-ában 2001 és 2016 között

A tanácsadóhoz a vállalkozás stabilitásának megőrzése céljából fordulók aránya jelentősen csökkent 2005-06 és 2011-12 között: 29\%-ról 17\%-ra. Ehhez hozzájárulhatnak a 2008-as pénzügyi világválságot követő megszorítások, recesszió, leépítések: kevesebb pénz jut külső tanácsadó megbízására, amikor a megrendelések csökkennek, amikor a munkatársak bérének kigazdálkodása is problémába ütközik. A válság lecsengését követően 2015-16-ra visszaállt az igény, bár még nem teljesen a válság előtti szintre.

A kritikus helyzetek kezelésében, a válságok szakszerü menedzselésében és a megelőzésben egyaránt meghatározó szerepet játszhatnak a külső szakemberek, a tanácsadók. A gazdaság fejlődésének velejárója a vállalati válságok, csődök kialakulása, a megszűnés és felszámolás. Csőd esetén vagyonfelügyelő, felszámolásnál felszámoló kijelölését a törvény előírja. Jogutód nélküli megszünésnél, a végelszámolásnál a társaság vezetőjének hatásköre nem korlátozott: a végelszámoló általában a gazdasági szerv vezetője (a folyamat egyszerübb lefolytatása érdekében igénybe vehet nagy rutinnal rendelkező tanácsadót) [18]. A kritikus helyzetek kezelése céljából igénybevett tanácsadási szolgáltatást szemlélteti a 9 . ábra a megvizsgált ügyfelek százalékában:

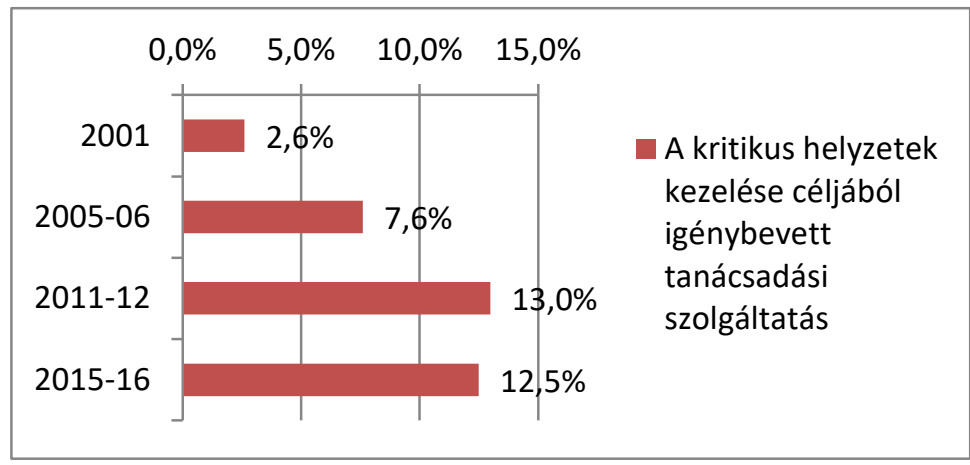

9. ábra. A kritikus helyzetek kezelése céljából igénybevett tanácsadási szolgáltatás alakulása a megvizsgált ügyfelek \%-ában 2001 és 2016 között

A vizsgált másfél évtizedben jelentősen növekedett a tanácsadási szolgáltatást a kritikus helyzetek kezelése céljából igénybevevők aránya. Bár meg kell jegyezni, hogy a felméréseink alapján ez az indok a legkevésbé fontos érv a tanácsadók megkeresésére: 2015-16-ban az ügyfelek 12,5\%-ka jelezte, hogy ez az érv játszott szerepet a tanácsadók felkérésében. 


\subsection{Speciális okok a gazdaság általános állapotának függvényében}

A speciális okok másik része a gazdaság általános állapotához köthető. Sokáig megdönthetetlennek tartották az Amerikai Tanácsadó Mérnökök Szövetségének megfigyelése alapján létrejött felfogást [19], mely szerint a tanácsadás ellenáll a gazdasági élet ingadozásainak, változásainak. Hosszú évek üzleti trendjei alapján azt szürték le, hogy az ügyfeleknek két okból van szükségük tanácsadóra:

- Konjunktúra idején a cégeknek általában van pénzük a külső tudás és erőforrás megszerzésére, a tanácsadók szolgáltatásának igénybevételére, másrészt a tanácsadó segíthet nekik pénzük befektetésében, mely jelentős hatással lehet tanácsadás tevékenységének bővülésére;

- Recesszió, válság idején a különböző cégek, szervezetek és intézmények a költségeik csökkentése érdekében fordulnak tanácsadóhoz, céljuk, hogy pénzt takarítsanak meg, hogy életben maradjanak, és a gazdaság virágzásakor legyen pénzük a verseny megkívánta beruházásokra és fejlesztésekre [20].

A tanácsadási forgalom és a GDP időbeli alakulását szemlélteti a 10. ábra [21]:

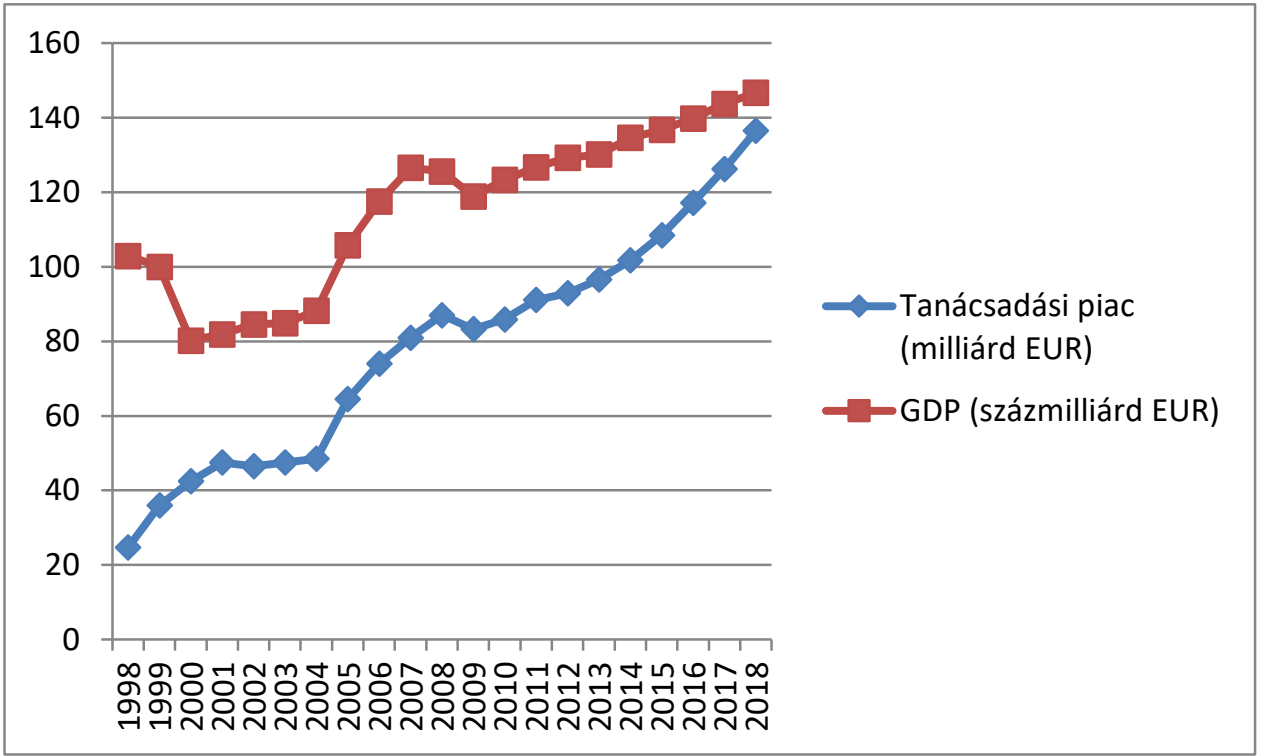

10. ábra. Az európai tanácsadási piac volumene és a GDP alakulása 1998 és 2018 között

A FEACO 1998 és 2018 közötti adatai alapján elvégzett korrelációs vizsgálat eredménye: a GDP és az európai tanácsadási forgalom alakulása között erős, pozitív irányú kapcsolat mutatható ki $(r=0,918 \mathrm{p}=0,0)^{*}$, tehát a FEACO tanácsadási piacra vonatkozó felmérései a fenti hipotézist nem támasztják alá. $A$ konjunktúra valóban pozitívan hat a tanácsadás igénybevételére, a recesszió hatása viszont negatív: kevesebb pénzt költenek tanácsadásra.

\section{4. Összefoglalás, következtetések}

Fontos érv a tanácsadó alkalmazására a vállalat stabilitásának megörzése. A verseny a legtöbb területen olyan intenzív, hogy a piaci pozíció megörzése érdekében is komoly lépéseket kell tenni (pl. termékek folyamatos fejlesztése, információ technológiai rendszer kiépítése stb.), illetve fontos a vállalkozás zavartalan, törvényes müködésének a biztosítása (pl. pénzügyi, adóügyi tanácsadás stb.). 2001-ben és 2005-06-ban ez volt a tanácsadási szolgáltatás igénybevételének legfontosabb indoka: a megvizsgált vállalkozások mintegy harmada (30\%-a) ebböl a célból vette igénybe a szolgáltatást. Ezt követte a vállalkozás növelésének segítésére irányuló megkeresés (2005-ben 25\%). 2011-12-ben némileg változott a helyzet, a 2008-as pénzügyi válság

\footnotetext{
* Pearson correlation (GDP-tan forg)=0,918 P=0,0 100\%-os megbízhatósággal van kapcsolat (erős, pozitív) a két változó között
} 
következményeként (kereslet csökkenés, megszorítások, leépítések) a legtöbb területen jelentős csökkenés figyelhető meg (pl. stratégiai, müködési, humán erőforrás tanácsadás), ugyanakkor kis mértékben növekedett az informatikai tanácsadás, és jelentősen a kiszervezési tanácsadás valamint a kritikus helyzetek kezelésére irányuló megkeresések aránya. A válság lecsengését követően a legtöbb területen visszaállt az igény a válság elötti szintre. Ez alól a stratégiai tanácsadás a kivétel, ahol az európai és magyarországi trenddel összefüggésben folyamatos csökkenés figyelhetö meg: a szakemberek egyre inkább vállalaton belül szeretnének foglalkozni a stratégiai kérdésekkel, nem külső szakértő igénybe vételével. Részaránya még ennek ellenére is igen jelentős: felmérésünk szerint a vállalkozások majdnem kétharmada $(62,5 \%$-a) ezen a területen is igénybe vette a szolgáltatást. Ugyanakkor igen kedvező tendencia, hogy egyre többen a bővülés, a vállalkozásuk növelése érdekében igénylik a külső segítséget: 2015-16-ban már majdnem minden harmadik ügyfél $(31,3 \%)$ jelölte meg ezt az okot.

A GDP és az európai tanácsadási forgalom alakulása között erős, pozitív irányú kapcsolat mutatható ki: a konjunktúra pozitívan hat a szolgáltatás igénybevételére, többen, több pénzt fordítanak tanácsadásra, a recesszió hatása viszont negatív, kevesebb pénzt áldoznak a külső szolgáltató megbízására. Ugyanakkor válság hatására nem egyformán csökken a kereslet az egyes tanácsadási területek iránt: a tanácsadási piac általános szükülése mellett megfigyelhető a területek kismértékü átrendeződése is.

\section{Irodalomjegyzék}

[1] Tokár-Szadai, Á. [2012]: Az üzleti tanácsadási rendszer modellje Vezetéstudomány XLIII. évfolyam (különszám) pp.66-73

[2] Tokár-Szadai Á. [2017]: A vezetési tanácsadók kiválasztásának szempontjai VEZETÉSTUDOMÁNY XLVIII:(6-7) pp. 39-48.

[3] Kubr, M. (ed.) [2002]: Management consulting A guide to the profession (fourth edition) ILO Geneva p.10

[4] Glückler, J. -Armbrüster, T. [2003]: Bridging Uncertainty in Management Consulting: The Mechanisms of Trust and Networked Reputation (Organization Studies 24 (2)) pp. 269-297

[5] Mitchell, V.W. - Moutinho, L. - Lewis, B.R. [2003]: Risk Reduction in Purchasing Organizational Professional Services (Service Industries Journal 23 (5)) pp. 1-19

[6] Pemer, F. - Werr, A. [2013]: The Uncertain Management Consulting Services Client (ISSN: 0020-8825 International Studies of Management \& Organization vol. 43, no. 3) pp. 22-40

[7] Maister, D. [2003]: Managing the Professional Service Firm (Simon\&Schuster, London UK)

[8] Sturdy [1997]: The Consultancy Process -An Insecure Business? Journal of Management Studies 34 (3): pp. 389 413

[9] Bergholz, H. [1999]: Do More Than Fix My Company (Journal of Management Consulting 10 (4)) pp. 29-33

[10] Mitchell, V.W. [1994]:Problems and Risks in the Purchasing of Consultancy Services (Service Industries Journal 14 (3)) pp. 315-339

[11] Bäcklund, J. - Werr, A. [2008]: Constructing the Legitimate Buyer of Management Consulting Services (Journal of Organizational Change Management 21 (6)) pp. 758-772

[12] Tokár-Szadai Á [2010]: Tanácsadók és vállalkozók tanácsadási értékrendje Borsod-Abaúj-Zemplén megyében Miskolc, PhD értekezés, $250 \mathrm{p}$.

[13] Woog Marc. A - Rüeger Brian [1997]: Die Unternehmensberatung im Umbruch, IO Management $11 / 1997$

[14] Höselbarth, F. (2000): Veränderungsbereitschaft als Methode, Managementberater 2000. March

[15] Poór J. [2010]: Menedzsment tanácsadási kézikönyv Akadémiai Kiadó, Budapest p. 696

[16] Szilágyiné Fülöp E. (2015): A kamarák vállalkozásfejlesztési tevékenysége különös tekintettel a szolgáltatások megítélésére -BOKIK esettanulmány In: Veresné Somosi Mariann, Lipták Katalin (ed.) „Mérleg és Kihívások” IX. Nemzetközi Tudományos Konferencia = „Balance and Challenges” IX. International Scientific Conference: Konferencia Kiadvány = Proceedings 948 p. ISBN 978-963-358-098-1 pp. 903-912.

[17] Vékás I [1996]: Finanszírozás-gazdaságtan Aula Kiadó, Budapest

[18] Csider L. [1993]: Félelmek, illúziók, realitások Figyelö, okt. 28

[19] Poór J (2005): A menedzsment tanácsadás fejlődési tendenciái ISBN 9630581981 Akadémiai Kiadó Budapest, p 265

[20] Kelley, R.E (1986): Consulting The Complete Guide to a Profitable Career. Scribner, New York

[21] FEACO Survey of the Management Consultancy market 1998, 1999, 2000, 2001, 2002, 2003, 2004, 2005-06, 2007-08, 2008-09, 2010-11, 2011-12, 2014-15, 2015-16, 2016-17, 2017-18 http://www.feaco.org/en/index-actionmarketInformation.html (letöltve: 2019. július)

[22] Tokár-Szadai Á. (2019): Készítsünk üzleti tervet! Üzleti tervezés az alapoktól Riga, Lettország : GlobeEdit International Book Market Service Ltd. OmniScriptum Publishing Group, 97 p. ISBN: 9786139414581 